\title{
Gangliosides Alter Morphology and Growth of Astrocytes and Increase the Activity of Choline Acetyltransferase in Cultures of Dissociated Septal Cells
}

\author{
FRANZ HEFTI, ${ }^{1}$ JUKKA HARTIKKA, AND WILLI FRICK
}

Preclinical Research. Sandoz Ltd., CH-4002 Basel, Switzerland

\begin{abstract}
Administration of gangliosides has been reported to stimulate regeneration of motoneurons and of central dopaminergic and cholinergic neurons. To shed light on the mechanism by which gangliosides mediate the effects on cholinergic neurons, we studied their actions on cultures of cells dissociated from the septal area of fetal rat brains. These cultures contain cholinergic neurons, which, in vivo, give rise to the cholinergic septo-hippocampal pathway. Gangliosides produced prominent changes in the morphological appearance of the cultures. In contrast to control cultures, which contained many process-bearing cells and a confluent layer of flat cells, there were no flat cells in cultures grown in the presence of gangliosides ( 0.2 to $0.8 \mathrm{mg} / \mathrm{ml}$ of medium). Using immunocytochemical visualization of the astrocytic marker glial fibrillary acid protein, it was shown that all astrocytes in cultures grown in the presence of gangliosides exhibited the morphology of process-bearing cells, whereas in control cultures astrocytes represented the majority of the flat cells. Furthermore, gangliosides attenuated astrocytic proliferation. The effects of gangliosides apparently were not mediated by CAMP, since they could be differentiated from actions of forskolin, an activator of adenylate cyclase. Astrocytic growth and morphology were affected by ganglioside mixtures of various sources and composition and also by the pure gangliosides $\mathrm{GM}_{1}$ and $\mathrm{GD}_{1 a}$, whereas lipid and carbohydrate components of gangliosides were ineffective. In contrast to the prominent effects on astrocytes, gangliosides failed to significantly alter survival or fiber growth of cholinergic neurons. However, similar to nerve growth factor (NGF) (Hefti, F., J. Hartikka, F. Eckenstein, H. Gnahn, R. Heumann, and $M$. Schwab (1985) Neuroscience 14: 55-68), gangliosides elevated the activity of choline acetyltransferase (ChAT) in the cultures. The NGF-mediated increase in ChAT activity was not potentiated by gangliosides. These findings indicate that gangliosides differentially affect glial and neuronal cells. Since astrocytic growth is believed to be one of the factors inhibiting neuronal regeneration in the CNS, the attenuation of astrocytic proliferation by gangliosides might represent the basis of their facilitatory effect on regenerative processes.
\end{abstract}

Rcceived Scptember 5, 1984; Reviscd December 4, 1984 Accepted December 11, 1984

'To whom correspondence should be sent, at his present address: Department of Neurology, University of Miami, Miami, FL 33101.
Gangliosides are glycosphingolipids highly abundant in the CNS. The fact that they are differentially regulated during development is suggestive of an important role in CNS development and function (for review, see Fishman and Brady, 1970; Ando, 1983). Several recent reports indicate that exogenously administered gangliosides might accelerate regeneration and sprouting of neuronal fibers in animals with experimentally induced lesions (Ceccarelli et al., 1976; Gorio et al., 1980, 1983; Sparrow and Grafstein, 1982; Wojcik et al., 1982; Agnati et al., 1983; Toffano et al., 1983, 1984; Norido et al., 1984; Robb and Keynes, 1984). Furthermore, exogenously administered gangliosides have been shown to accelerate the functional recovery of animals with lesions that produce behavioral deficits (Ceccarelli et al., 1976; Agnati et al., 1983; Karpiak, 1983). In support of thesc findings obtaincd in vivo, gangliosides have been reported to stimulate fiber formation of neuroblastoma cells in vitro (Morgan and Seifert, 1979; Dimpfel et al., 1981; Roisen et al., 1981; Leon et al., 1982; Byrne et al., 1983; Ferrari et al., 1983; Rybak et al., 1983; Facci et al., 1984; Spero and Roisen, 1984).

We have been studying primary cultures of dissociated cclls from the septal region of fetal rat brains (Hefti et al., 1984; Rüegg and Hefti, 1984). These cultures contain cholinergic neurons which give rise to the cholinergic septo-hippocampal pathway in vivo. The culture system is used to investigate regulation of and influences on survival, fiber elongation, and differentiation of cholinergic neurons. Recently, we reported that nerve growth factor (NGF) enhances the expression of choline acetyltransferase (ChAT) activity by these neurons (Hefti et al., 1985). Given the findings that gangliosides stimulate growth of neuronal fibers in vivo and in vitro, we decided to assess their effects on our culture system. We studied the influence of gangliosides on growth and morphology of cultured cells. We specially investigated the effects on cholinergic neurons, since gangliosides have been reported to promote regeneration of cholinergic septo-hippocampal fibers in vivo (Wojcik et al., 1982). Since it has been hypothesized that gangliosides potentiate the action of growth factors (Gorio et al., 1983), we analyzed the influence of gangliosides on the NGF-mediated increase in ChAT activity.

\section{Materials and Methods}

Cultures. Brains were removed from fetal rats (Wistar) of embryonic day 17, and the septal area was dissected under a stereomicroscope. Tissue pieces were transferred to $L-15$ medium containing $25 \mathrm{mM} H E P E S$ buffer $(L$ 15/HEPES medium, Grand Island Biological Co. (GIBCO)). They were minced and incubated in $0.5 \%$ trypsin (GIBCO) and $0.05 \%$ DNase (type 1, Sigma) in Dulbecco's phosphate-buffered saline (PBS) for $15 \mathrm{~min}$ at $37^{\circ} \mathrm{C}$. Pieces were then washed twice with L-15/HEPES medium, and cells were dissociated by mild trituration using a fire-polished Pasteur pipette. The cell suspension was centrifuged at $1000 \times g$ and the cells were resuspended in 1 to $2 \mathrm{ml}$ of growth medium (cf. below). For biochemical experiments, an aliquot yielding 0.2 to $0.5 \times 10^{6}$ viable cells (counted after 1 day in culture) were added to each well of $16 \mathrm{~mm}$ diameter in multiwell plates (Costar). For 
cytochemical studies, an aliquot resulting in 0.2 to $1 \times 10^{6}$ viable cells was added to each $35 \mathrm{~mm}$ culture dish (Falcon). One rat embryo yielded 1 to 2 $\times 10^{6}$ septal neurons counted after 1 day in culture.

Culture dishes were coated with polyethyleneimine (PEI, Sigma Chemical Co.). A solution of $1 \mathrm{mg} / \mathrm{ml}$ of $\mathrm{PEI}$ in $0.15 \mathrm{M}$ sodium borate buffer, $\mathrm{pH} 8.3$, was applied overnight. Then the dishes were washed three times with PBS. PEI was introduced as replacement for polyornithine because of low costs. Coating in PEl, polyornithine, or polylysine supported the survival of an equal number of neurons. A detailed comparison of the coating procedures has appeared elsewhere (Rüegg and Hefti, 1984).

Neurons were grown in a modified L-15 medium containing 5\% horse serum and $1 \%$ rat serum. The $L-15$ medium was a modification of the growth medium developed by Mains and Patterson (19/3) for sympathetic neurons. It consisted of L-15 medium (GIBCO) and the following additions: $11.3 \mathrm{gm} /$ liter of glucose, $1.1 \mathrm{gm} /$ liter of glutamine, $5 \mathrm{mg} /$ /iter of $\beta$-alanine, $15 \mathrm{mg} /$ liter of aspartic acid, $15 \mathrm{mg} /$ /iter of cystine, $15 \mathrm{mg} / \mathrm{liter}$ of glutamic acid, $5 \mathrm{mg} /$ liter of $\rho$-aminobenzoic acid, $64 \mathrm{mg} / \mathrm{liter}$ of ascorbic acid, $10 \mathrm{mg} / \mathrm{liter}$ of choline chloride, $25 \mathrm{mg} /$ liter of fumaric acid, $3 \mathrm{mg} /$ liter of glutathione, $60 \mathrm{mg} /$ liter of imidazole, $10 \mathrm{mg} /$ liter of inositol, $0.5 \mathrm{mg} /$ liter of $\alpha$-lipoic acid, and 2 $\mathrm{mg} /$ /iter of vitamine $B_{12}$. Eighty milliliters of this modified $L-15$ medium were mixed with $20 \mathrm{ml}$ of $0.15 \mathrm{M} \mathrm{NaHCO}_{3}, 5 \mathrm{ml}$ of horsc scrum (GIBCO), and 1 $\mathrm{mi}$ of rat serum (prepared in our laboratories). Sera were heat inactivated (30 $\min , 56^{\circ} \mathrm{C}$ ). Cells were grown at $37^{\circ} \mathrm{C}$ in $5 \%$ of $\mathrm{CO}_{2}$. The medium was exchanged after 3 days.

Glial fibrillary acid protein (GFAP) immunocytochemistry. GFAP was visualized immunocytochemically according to the method of Manthorpe et al. (1979). Cultures were fixed with a mixture of 3 parts of acetone and 2 parts of ethanol. Then they were incubated with a rabbit antiserum to human GFAP (Dakopatts) and fluorescein isothiocyanate-conjugated goat antibodies to rabbit immunoglobulins (Miles Laboratories). This procedure stained flat cells or process-bearing cells with processes of variable diameter. No staining was observed when the specific antiserum was replaced by an unspecific rabbit serum.

The total number of GFAP-positive cells was established by counting them in randomly distributed visual fields corresponding to 1 to $2 \%$ of the total area of the culture dish.

Acetycholinesterase (AChE) cytochemistry. A modification of the histochemrcal procedure of Geneser-Jensen and Blackstad (1971) was used. Cultures were fixed with $4 \%$ formaldehyde, washed with PBS, and then incubated for 3 days at $4^{\circ} \mathrm{C}$ in $50 \mathrm{~mm}$ acetate buffer, $\mathrm{pH} 5.0$, containing 4 $\mathrm{mm}$ acetylthiocholine, $2 \mathrm{~mm}$ copper sulfate, $10 \mathrm{~mm}$ glycine, and $10 \mathrm{mg} / \mathrm{ml}$ of gelatin. Inclusion of gelatin prevented diffusion of the reaction product. Nonspecific cholinesterases were inhibited by inclusion of $0.2 \mathrm{~mm}$ ethopropazine in the incubation medium. After the incubation, the gelatin was dissolved by incubating the cultures briefly at $37^{\circ} \mathrm{C}$. They were then rinsed with $\mathrm{H}_{2} \mathrm{O}$, exposed for 1 min to $1.25 \% \mathrm{Na}_{2} \mathrm{~S}$, washed with $\mathrm{H}_{2} \mathrm{O}$, and exposed for $1 \mathrm{~min}$ to $1 \% \mathrm{AgNO}_{3}$. The cultures were then washed with $\mathrm{H}_{2} \mathrm{O}$ and embedded in glycerol gelatin. Specificity of the staining was tested using the AChE inhibitor 1,5-bis-(4-allyldimethyl-ammoniurmphenyl)-pentan-3-one dibromide (BW 284C51).

To estimate the number of fibers per neuron, the cells were photographed and a ring with a diameter corresponding to $500 \mu \mathrm{m}$ was drawn around the cell body. The number of processes intersecting with the ring served as the index of fiber growth.

Biochemical determinations. Cultures were washed three times with PBS and were homogenized by sonication in $200 \mu$ of a $50 \mathrm{~mm}$ Tris. HCl buffer, $\mathrm{pH} 6.0$, containing $0.1 \%$ Triton $X-100$. Aliquots of the homogenate were taken for the determination of ChAT activity according to the method of Fonnum (1975) or for protein determination according to the method of Bradford (1976) using bovine $\gamma$-globulin as a standard. Specificity of the enzyme determination was assessed by using the ChAT-inhibitor $N$-hydroxyethyl-4-(1-naphtyl-vinyl)pyridium bromide (Calbiochem)

Chemicals. Chemicals of analytical grade were purchased from Merck (Darmstadt, Federal Republic of Germany), Serva (Heidelberg, Federal Republic of Germany), or Sigma, if not otherwise stated. Media for tissue cultures were obtained from GIBCO. Purified ganglioside mixtures were purchased from Fidia (Abano Terme, Italy), Serva, and Sigma. If not otherwise stated, experiments were carried out with the defined mixture Cronassial (Fidia), containing $2.1 \mathrm{mg}$ of $\mathrm{GM}_{1}, 4 \mathrm{mg}$ of $\mathrm{GD}_{1 \mathrm{a}}, 1.6 \mathrm{mg}$ of $\mathrm{GD}_{1 \mathrm{~b}}, 1.9 \mathrm{mg}$ of GT $1 \mathrm{~b}$ per milliliter. Aliquots of the original solution were added to the culture medium. The vehicle of this ganglioside mixture was composed of physiological saline containing $10 \mathrm{~mm}$ sodium phosphate. Control cultures therefore were given equal amounts of PBS. Additions never exceeded $50 \mu \mathrm{l} / \mathrm{ml}$ of culture mediurn. This arnount of PBS railed to allect the cullures. GM $\mathrm{G}_{1}$ and $\mathrm{GD}_{1 \mathrm{a}}$ were purified from Cronassial using methods described by Tettamanti et al. (1973) and were dissolved in PBS. Mouse NGF was purified from adult mouse submandibular glands according to the method of Bocchini and Angeletti (1969), with the modifications described by Suda et al. (1978).

\section{Results}

Effects of gangliosides on cell morphology. Control cultures grown in the absence of gangliosides contained both cells with a spherical cell body and long, thin processes of constant diameter (neuron-like cells) and flat cells with a sheet-like appearance (Fig. 1, $A$ and $B$ ). During the first 6 days after plating, neuron-like cells were predominant. The number of flat cells increased gradually, and 6 to 10 days after plating, these cells formed a confluent layer covering the entire surface of the culture dish. Thereafter, the number of neuron-like cells declined. After several weeks the cultures almost exclusively contained flat cells.

Cultures grown in medium containing $0.5 \mathrm{mg} / \mathrm{ml}$ of a ganglioside mixture (containing 27\% GM $1,40 \% \mathrm{GD}_{1 \mathrm{a}}, 16 \% \mathrm{GD}_{1 \mathrm{~b}}, 17 \% \mathrm{GT}_{1 \mathrm{~b}}$ ) contained no flat cells (Fig. $1 \mathrm{C}$ and $D$ ). Most cells exhibited a neuron-like appearance. Other cells with rounded cell bodies had thick processes of variable diameter. Cell bodies had a tendency to aggregate. In areas of the culture dishes not covered with cell bodies, a network of processes of various diameters was observed. Most of these fibers were straight (Fig. 1D). The density of processes increased with culture time. The cultures were viable for approximately 3 weeks and degenerated thereafter.

We had shown earlier that flat cells in control cultures are mainly astrocytes (Hefti et al., 1985). However, since this cell type can appear both as flat and as process-bearing cells in vitro (Manthorpe ct al., 1979; Raff et al., 1983), we tested the possibility that gangliosides specifically affected astrocyte morphology in our cultures.

Effects of gangliosides on astrocytes. Astrocytes were identified by their content of GFAP, the major constituent of glial intermediary filaments, which was visualized immunocytochemically. In control cultures, virtually all flat ceils were positively stained for GFAP (Fig. $2 A$ ). The glial filaments were either homogeneously distributed around the cell nucleus or they radiated in a star-like manner from the nucleus. The number of astrocytes increased gradually with culture time (Table I).

Cultures grown in the presence of gangliosides contained only process-bearing astrocytes (Fig. 2, $C$ and D). These processes exhibited various diameters. The number of astrocytes in ganglioside-treated cultures increased up to 10 days after plating and thereafter remained constant. At all time points the number of astrocytes in ganglioside-treated cultures was considerably lower than in control cultures (Table I), indicating that gangliosides inhibited the proliferation of astrocytes.

Since flat astrocytes are transformed into process-bearing cells by treatments increasing intracellular cAMP levels (Lim et al., 1973; Shapiro, 1973; Manthorpe et al., 1979), wi, tested whether the effect of gangliosides was due to the same mec'ianism. Cultures therefore were grown in the presence of forskolin, an activator of adenylate cyclase (Metzger and Linder, 1981; Seamon et al., 1981). As with cultures treated with gangliosides, forskolin-treated cultures only contained process-bearing astrocytes. However, these cells exhibited a morphology slightly different from that of astrocytes grown in the presence of gangliosides. Their processes were shorter than those of ganglioside-treated astrocytes and gave rise to more ramifications (Fig. 2B). Furthermore, the number of astrocytes in cultures grown in the presence of forskolin was slightly higher than that of control cultures (Table I), suggesting that, contrary to gangliosides, forskolin did not inhibit but, rather, stimulated astrocytic proliferation. Accordingly, combining forskolin with gangliosides resulted in a number of astrocytes intermediate between ganglioside-treated and control cultures (Table I). These findings suggest that gangliosides and forskolin affect astrocytes by different mechanisms and that the ganglioside-induced alteration of astrocytic morphology is not due to an elevation of intracellular cAMP levels.

Dose-response relationship and specificity of ganglioside effect. 

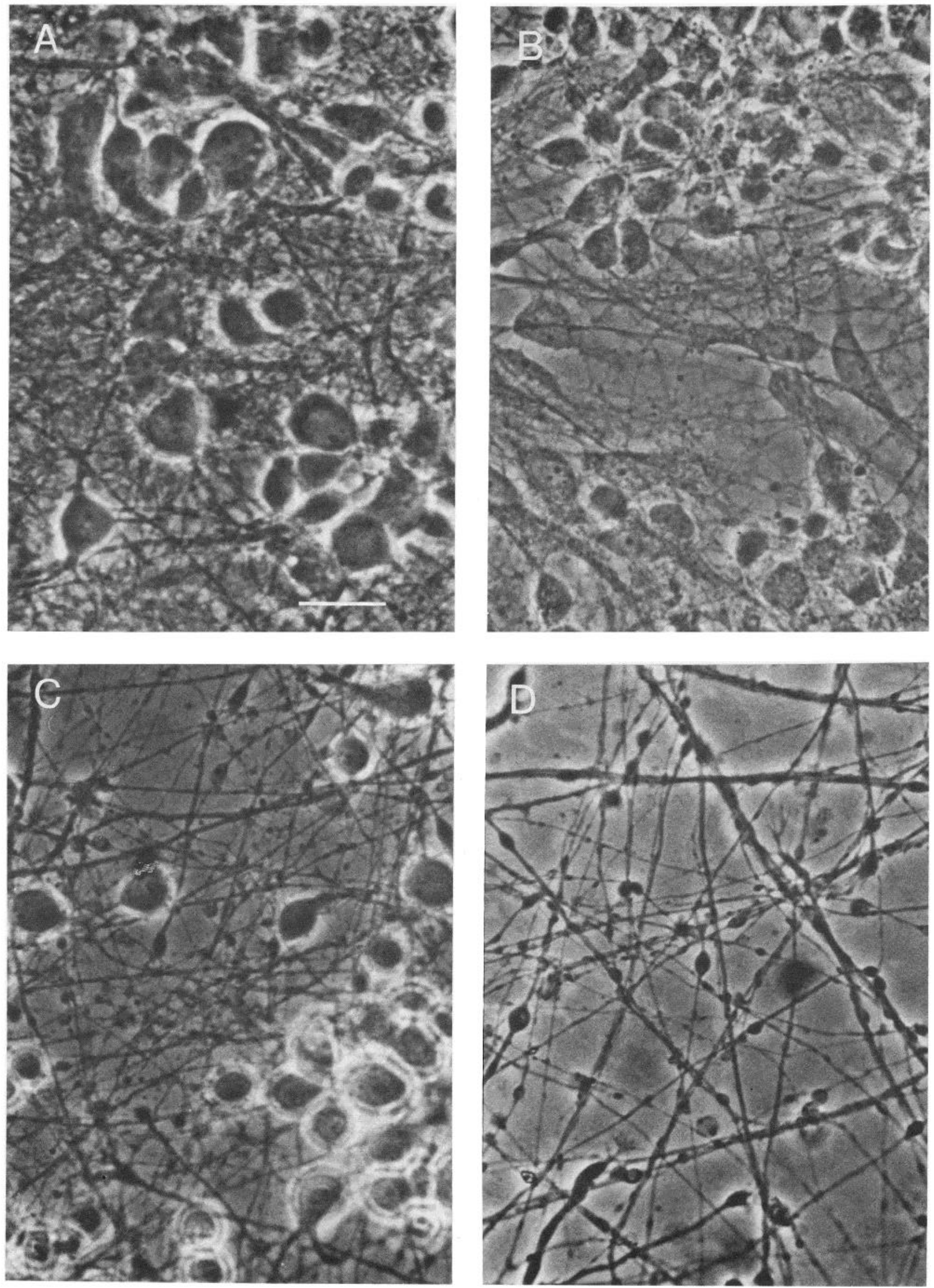

Figure 1. Effect of gangliosides on cultured septal cells. $A$ and $B$, Control cultures grown for 10 days. They are composed of neuron-like cells and flat cells which together form a dense layer covering the entire surface of the culture dish. Flat cells are clearly visible in areas without neuron-like cells $(B)$. $C$ and $D$, Cultures grown for 10 days in medium containing $0.5 \mathrm{mg} / \mathrm{ml} \mathrm{GM}_{1}, \mathrm{GD}_{1 \mathrm{a}}, \mathrm{GD}_{1 \mathrm{~b}}$ and $\mathrm{GT}_{1 \mathrm{~b}}$. They contain only cells with a neuron-like appearance with processes of variable diameter. Phase contrast optics. Bar, $20 \mu \mathrm{m}$ for $A$ to $D$. 

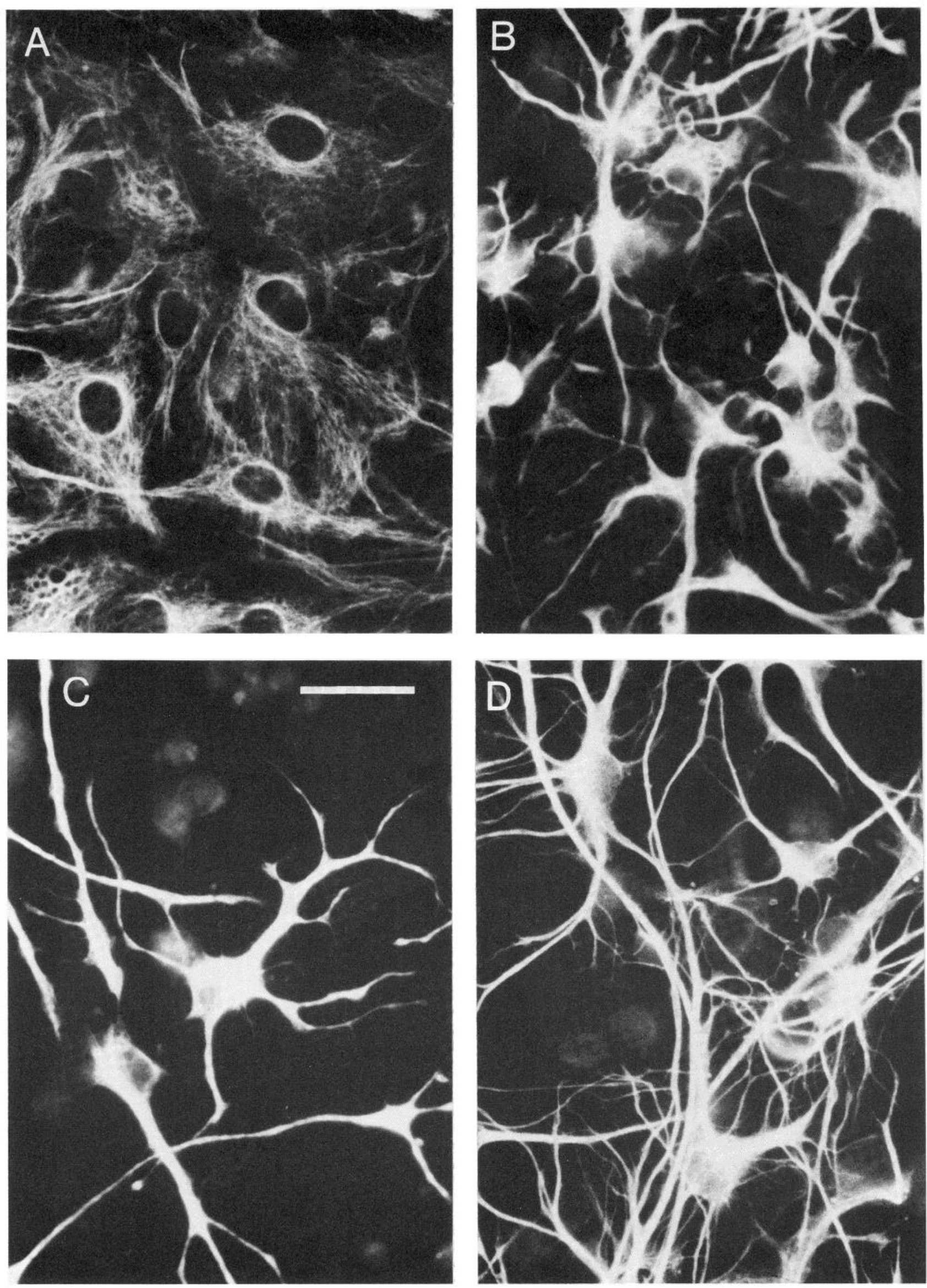

Figure 2. Effect of gangliosides on astrocyte morphology. Astrocytes were identified by GFAP immunocytochemistry. $A$, Cultures grown for 10 days in control medium. $B$, Cultures grown in the presence of forskolin $\left(10^{-5} \mathrm{M}\right) . C$ and $D$, Cultures grown in medium containing $0.5 \mathrm{mg} / \mathrm{ml}$ of ganglioside mixture. Forskolin and gangliosides were present during the entire culture time (10 days). Bar, $20 \mu \mathrm{m}$ for $A$ to $D$. 
TABLE I

Effects of gangliosides on number of astrocytes

Cultures of dissociated septal cells were grown for the indicated times in medium containing a ganglioside mixture $(0.5 \mathrm{mg} / \mathrm{ml})$ or forskolin $\left(10^{-5} \mathrm{M}\right)$. These additions were present throughout the whole culture time. Astrocytes were identified by immunocytochemical visualization of GFAP.

\begin{tabular}{clc}
\hline Culture Time & \multicolumn{1}{c}{ Treatment } & $\begin{array}{c}\text { Astrocytes per } \\
\text { Dish }\left(\times 10^{-3}\right)\end{array}$ \\
\hline \multirow{2}{*}{2 days } & Controls & $66 \pm 10^{a}$ \\
& Gangliosides & $28 \pm 2^{b}$ \\
& Controls & $260 \pm 25$ \\
& Gangliosides & $64 \pm 15^{b}$ \\
& Forskolin & $310 \pm 24$ \\
& Gangliosides + forskolin & $175 \pm 25^{b}$ \\
& Controls & $>500^{c}$ \\
& Gangliosides & $207 \pm 23$ \\
& Controls & $>500^{\circ}$ \\
& Gangliosides & $195 \pm 26$ \\
\hline
\end{tabular}

a Values are mean \pm SEM, $n=6$

${ }^{b}$ Different from corresponding controls, $p<0.05$.

'High density of astrocytes precluded exact counting.

\section{Hg PROTEIN}

\section{PER DISH}

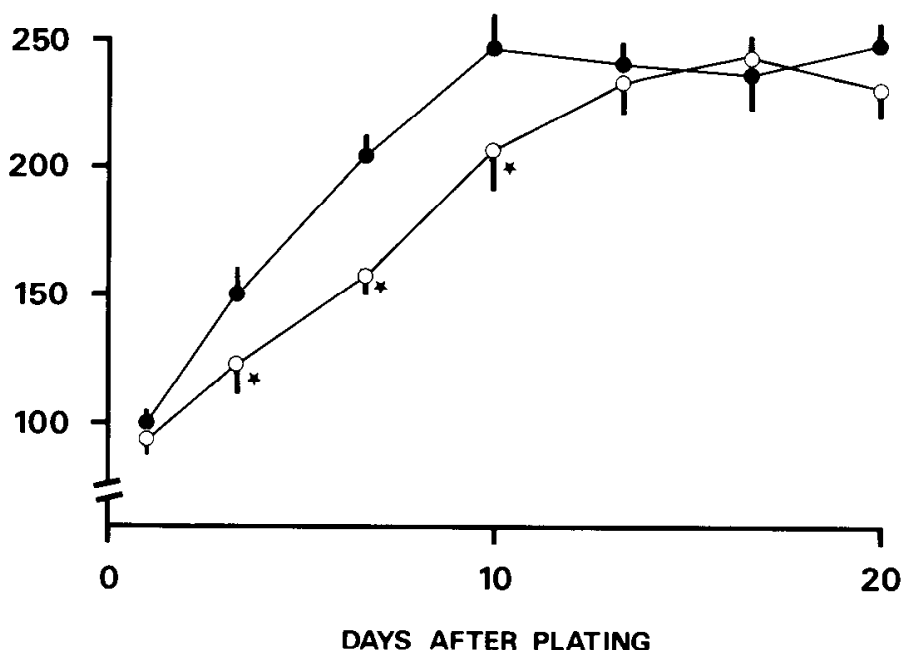

Figure 3. Effect of gangliosides on protein content of cultures of dissociated septal cells. The cells were grown in the absence $(0)$ or presence $(O)$ of a mixture of gangliosides $\left(0.5 \mathrm{mg} / \mathrm{ml}\right.$ of $\mathrm{GM}_{1}, G_{1 \mathrm{a}}, \mathrm{GD}_{1 \mathrm{~b}}$, and $\left.\mathrm{GT}_{1 \mathrm{~b}}\right)$. Bars represent SEM. *, significantly different from corresponding control level, $p$ $<0.01 ; n=8$.

The inhibition of astrocytic proliferation induced by gangliosides was reflected by a decreased protein content of the cultures. In control cultures, protein content increased until 10 days after plating and remained constant thereafter. In ganglioside-treated cultures, the increase was delayed by approximately 3 days (Fig. 3). Even though control and ganglioside-treated cultures had similar contents of protein after 12 days of growth, their morphological appearance was different. In control dishes, flat cells covered the entire surface of the dish, whereas ganglioside-treated cultures only contained cells with a neuron-like morphology. Probably because of the gradual loss of neuron-like cells in control cultures, their content of protein stabilized at a level which was also reached by ganglioside-treated cultures, despite the fact that they contained fewer astrocytes. The difference between ganglioside-treated and control cultures was maximal at day 7 after plating. Even though the decrease in protein content did not exceed $30 \%$, this ganglioside-mediated effect was reliably reproducible. The reduction in protein content after 7 days was therefore used as a quantitative indication to assess the doseresponse relationship and to assess the effectivity of various mixtures of gangliosides, pure gangliosides, and fragrnents of gangliosides. Significant decreases were seen with ganglioside concentrations exceeding $0.1 \mathrm{mg} / \mathrm{ml}$ (Fig. 4). The $E D_{50}$ of the response was estimated to range between 0.2 and $0.3 \mathrm{mg} / \mathrm{ml}$. However, this value could not be established precisely, because no clear plateau was reached with higher ganglioside concentrations. Ganglioside levels exceeding $0.8 \mathrm{mg} / \mathrm{ml}$ were toxic and resulted in cell death.

Ganglioside mixtures obtained from different sources were equally effective in changing the morphological appearance of cultures of septal cells and in reducing their protein content (Table II). An equal concentration $(w / v)$ of the purified ganglioside $\mathrm{GD}_{1 \mathrm{a}}$ had the same effect as ganglioside mixtures. $\mathrm{GM}_{1}$ at the same concentration was less effective. Lipid and carbohydrate constituents of gangliosides were ineffective in reducing the protein content of cultures, indicating that the entire ganglioside molecule is required to produce the effect.

Importance of coating of culture dishes for the effect of gangliosides. Culture dishes used in the present study were coated with $\mathrm{PEI}$, an artifical polycationic substrate with properties similar to those of the commonly used coating materials, polyornithine and polylysine. Gangliosides equally affected growth and morphology of astrocytes in dishes coated with any one of these polycationic substrates (Table III). In contrast to neurons, astrocytes proliferate on coated as well as on uncoated surfaces. It was therefore tested whether gangliosides also affect astrocytes that grow on uncoated plastic surfaces. A ganglioside mixture inhibiting astrocytic growth in PEIcoated dishes failed to change growth and morphology of septal cells growing in uncoated dishes (Table III). This finding suggests that gangliosides alter the interaction between astrocytes and the surface on which they grow. Gangliosides might produce this effect by inserting themselves in the membranes of astrocytes or by attaching themselves to the culture dish.

Gangliosides might alter properties of culture dish surfaces in a manner similar to polyornithine-attached neurite-promoting factors, which bind to polyornithine-coated surfaces and promote growth of

\section{jg PROTEIN \\ PER DISH}

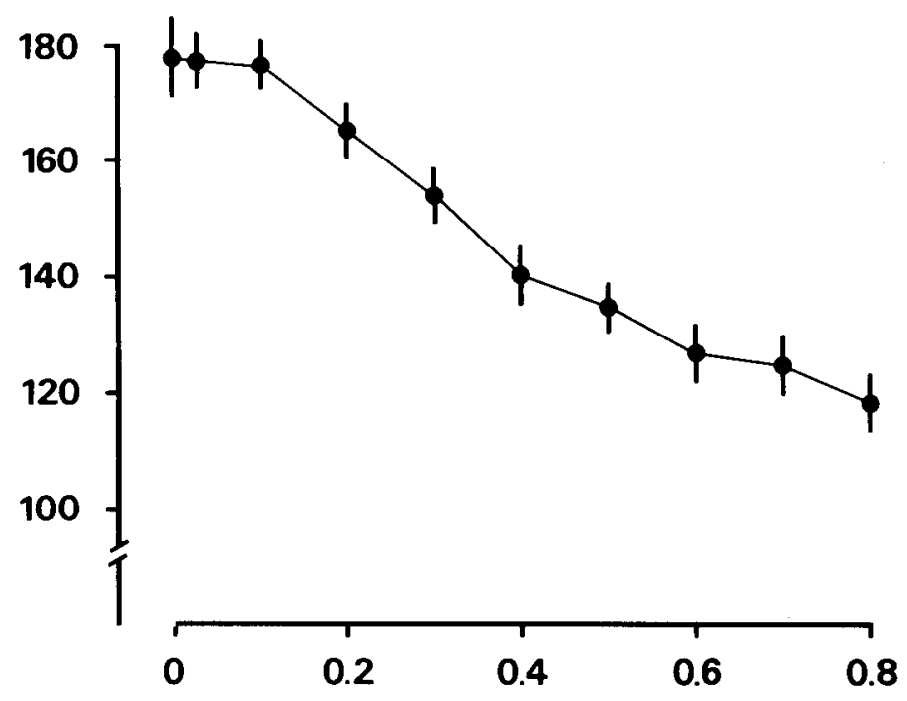

GANGLIOSIDE CONCENTRATION (mg/mI MEDIUM)

Figure 4. Dose-response relationship of the ganglioside-mediated decrease in protein content of cultures of dissociated septal cells. Cultures were grown for 7 days in the presence of a ganglioside mixture. Bars indicate $\mathrm{SEM} ; n=8$ to 12 . 
TABLE ॥

Effect of gangliosides and related compounds on protein content of cultures of dissociated septal cells

Cclls wcre grown for 7 days in the presence of the indicated substances and then were taken for biochemical determination of proteins. Compounds significantly reducing protein content produced the same changes in morphological appearance of the cultures as the defined ganglioside mixture (Cronassial, Fidia).

\begin{tabular}{|c|c|}
\hline Substance & $\begin{array}{c}\text { Protein } \\
(\mu \mathrm{g} / \text { dish })\end{array}$ \\
\hline Controls & $184 \pm 9^{a}$ \\
\hline \multicolumn{2}{|l|}{ Ganglioside mixtures: } \\
\hline $\begin{array}{l}\mathrm{GM}_{1}, \mathrm{GD}_{1 \mathrm{a}}, \mathrm{GD}_{1 \mathrm{~b}}, \mathrm{GT}_{1 \mathrm{~b}} \text {; (Cronassial, Fidia) } 0.5 \mathrm{mg} / \\
\mathrm{ml}\end{array}$ & $134 \pm 7^{b}$ \\
\hline Bovine brain gangliosides (Sigma) $0.5 \mathrm{mg} / \mathrm{ml}$ & $113 \pm 9^{b}$ \\
\hline Bovine brain gangliosides (Serva) $0.5 \mathrm{mg} / \mathrm{mll}$ & $120 \pm 12^{b}$ \\
\hline $\mathrm{GM}_{1}, 0.5 \mathrm{mg} / \mathrm{ml}, 0.3 ? \mathrm{~mm}$ & $160 \pm 10^{b}$ \\
\hline $\mathrm{GD}_{10}, 0.5 \mathrm{mg} / \mathrm{ml}, 0.32 \mathrm{~mm}$ & $127 \pm 16^{D}$ \\
\hline Spingosine $0.22 \mathrm{mg} / \mathrm{ml}, 0.32 \mathrm{~mm}$ & toxic \\
\hline $\begin{array}{l}\text { Ceramides (bovine brain, Sigma) } 0.2 \mathrm{mg} / \mathrm{ml}, 0.32 \\
\mathrm{~mm}^{c}\end{array}$ & toxic \\
\hline N-Acetylgalactosamine, $0.07 \mathrm{mg} / \mathrm{ml}, 0.32 \mathrm{~mm}$ & $201 \pm 13$ \\
\hline N-Acetylneuroaminic acid, $0.1 \mathrm{mg} / \mathrm{ml}, 0.32 \mathrm{~mm}$ & $184 \pm 15$ \\
\hline Galactose-1-phosphate, $0.13 \mathrm{mg} / \mathrm{ml}, 0.32 \mathrm{~mm}$ & $179 \pm 12$ \\
\hline
\end{tabular}

a Values are mean $\pm \mathrm{SEM}, n=8$ to 12

${ }^{b}$ Significantly different from controls, $p<0.01$.

'Molarity was calculated with the assumption that these compounds exclusively contain stearic acıd.

TABLE III

Influence of coating on the effect of gangliosides

Cultures were grown for 7 days in dishes treated using various coating procedures. Treated cultures grew in the presence of $0.5 \mathrm{mig} / \mathrm{mll}$ of a ganglioside mixture, which was present during the entire culture time.

\begin{tabular}{lll}
\hline \multirow{2}{*}{ Coating } & \multicolumn{2}{c}{ Protein $(\mu \mathrm{g} / \mathrm{dish})$} \\
\cline { 2 - 3 } & Controls & $\begin{array}{c}\text { Ganglioside } \\
\text { treated }\end{array}$ \\
\hline PEI & $262 \pm 7^{a}$ & $197 \pm 6^{b}$ \\
Polyornithine & $254 \pm 15$ & $208 \pm 15^{b}$ \\
Polylysine & $257 \pm 6$ & $187 \pm 11^{b}$ \\
Uncoated & $204 \pm 14$ & $207 \pm 8$ \\
Precoating with gangliosides $^{c}$ & $251 \pm 7$ & $244 \pm 4$ \\
\hline
\end{tabular}

${ }^{a}$ Values are mean \pm SEM, $n=8$.

${ }^{b}$ Significantly different from corresponding control, $p<0.01$.

${ }^{c}$ Dishes were coated first with PEl and then incubated for $24 \mathrm{hr}$ with medium containing gangliosides. This medium was removed before plating the cells.

neuronal cells (Adler et al., 1981). To test this possibility, culture dishes were first coated with PEI and then incubated with medium containing gangliosides. The ganglioside-containing medium then was removed before plating the cells. Such a precoating with gangliosides failed to affect growth and morphology of astrocytes (Table III), indicating that gangliosides have to be present in the medium to be effective.

Effect of gangliosides on cholinergic neurons. We had shown earlier that cultures of dissociated septal cells as prepared in the present study contain cholinergic neurons which, in vivo, project into the hippocampus (Hefti et al., 1985). Cholinergic neurons werc identified by ChAT immunocytochemistry and AChE cytochemistry. Of all the AChE-positive neurons, 94\% were co-stained for ChAT, indicating that $\mathrm{AChE}$ cytochemistry represents a reliable marker for cholinergic neurons in these cultures.

Gangliosides failed to affect survival of cholinergic cells. Cultures grown in the presence of gangliosides contained the same number of AChE-positive neurons as did control cultures (Table IV). The morphological appearance of AChE-positive neurons grown in the presence of gangliosides differed only slightly from that of neurons grown in control dishes (Fig. 5). Ganglioside treatment resulted in a slight (but not statistically significant) reduction in the number of processes of these cells (Table IV). Ganglioside-treated cultures contained AChE-positive processes running straight and unbranched for up to $0.5 \mathrm{~mm}$ (Fig. 5); such processes were not seen in control dishes. These findings suggest that gangliosides only marginally affected growth of cholinergic neurons in cultures of dissociated septal cells.

Cultures grown in the presence of gangliosides exhibited a higher activity of ChAT (measured biochemically) as compared to controls (Fig. 6). This effect became manifest after 10 days in culture, i.e. later than the ganglioside-mediated reduction in protein content (cf. Fig. 3). The ganglioside-induced increase in ChAT activity had the same dose-response relationship as the decrease in protein content (data not shown).

Gangliosides increased the absolute ChAT activity in septal cultures by $65 \%$. Growing the cultures in the presence of NGF resulted in an increase of $143 \%$ (Table V). Elevations in relative ChAT activity mediated by gangliosides and NGF were $100 \%$ and $145 \%$, respectively. The difference in extent of the increases of relative and absolute activities is due to the fact that gangliosides reduced the protein content. The elevations mediated by NGF and the gangliosides were not additive, suggesting that the level reached by NGF treatment represents a maximal value or, alternatively, that the two treatments act at least in part through a common mechanism.

\section{Dicussion}

The findings of the present study indicate that gangliosides ditterentially affect glial and neuronal cells in cultures of dissociated septal cells. Gangliosides inhibited proliferation and induced a change in morphology of astrocytes. The same treatment failed to affect survival and morphology of cholinergic neurons but stimulated their expression of ChAT activity.

The transformation of flat astrocytes into process-bearing cells was the most prominent change caused by the gangliosides. This completely altered the appearance of the cultures. No similar effect of exogenous gangliosides occurring in vivo or in vitro has been reported so far. The induction of a process-bearing morphology by gangliosides seems to be separable from a similar effect caused by treatments which elevate intracellular cAMP levels (Lim et al., 1973; Shapiro, 1973; Manthorpe et al., 1979). This is indicated by the fact that, in contrast to forskolin which stimulates adenylate cyclase (Metzger and Linder, 1981; Seamon et al., 1981), gangliosides also alterluated the proliferation of astrocytes. Furthermore, gangliosides only affected the morphology of astrocytes growing together with neurons in dishes coated with polycations, whereas forskolin and dibutyryl cAMP also alter the morphology of astrocytes growing without neurons in uncoated dishes (Lim et al., 1973; Shapiro, 1973; Manthorpe et al., 1979). Process-bearing aslrocyles have recently

TABLE IV

Effect of gangliosides on survival and fiber outgrowth of AChE-positive neurons

Cultures of dissociated septal cells were grown in the presence or absence of $0.5 \mathrm{mg} / \mathrm{ml}$ of a ganglioside mixture in the medium. After 10 days they were taken for cytochemical visualization of $A C h E$. To assess the number of processes, a ring of $0.5 \mathrm{~mm}$ was drawn around the cell body, and the number of processes intersecting with this ring was counted.

\begin{tabular}{lcc}
\hline & Controls & Ganglioside treated \\
\hline $\begin{array}{l}\text { AChE-positive neurons per } \\
\text { dish }\end{array}$ & $3520 \pm 190^{\circ}$ & $3670 \pm 430$ \\
$\begin{array}{c}\text { Number of fibers of AChE- } \\
\text { positive neurons }\end{array}$ & $15.8 \pm 2.1$ & $11.8 \pm 1.3$ \\
\hline
\end{tabular}

${ }^{a}$ Values are mean $\pm \operatorname{SEM}, n=20$ 

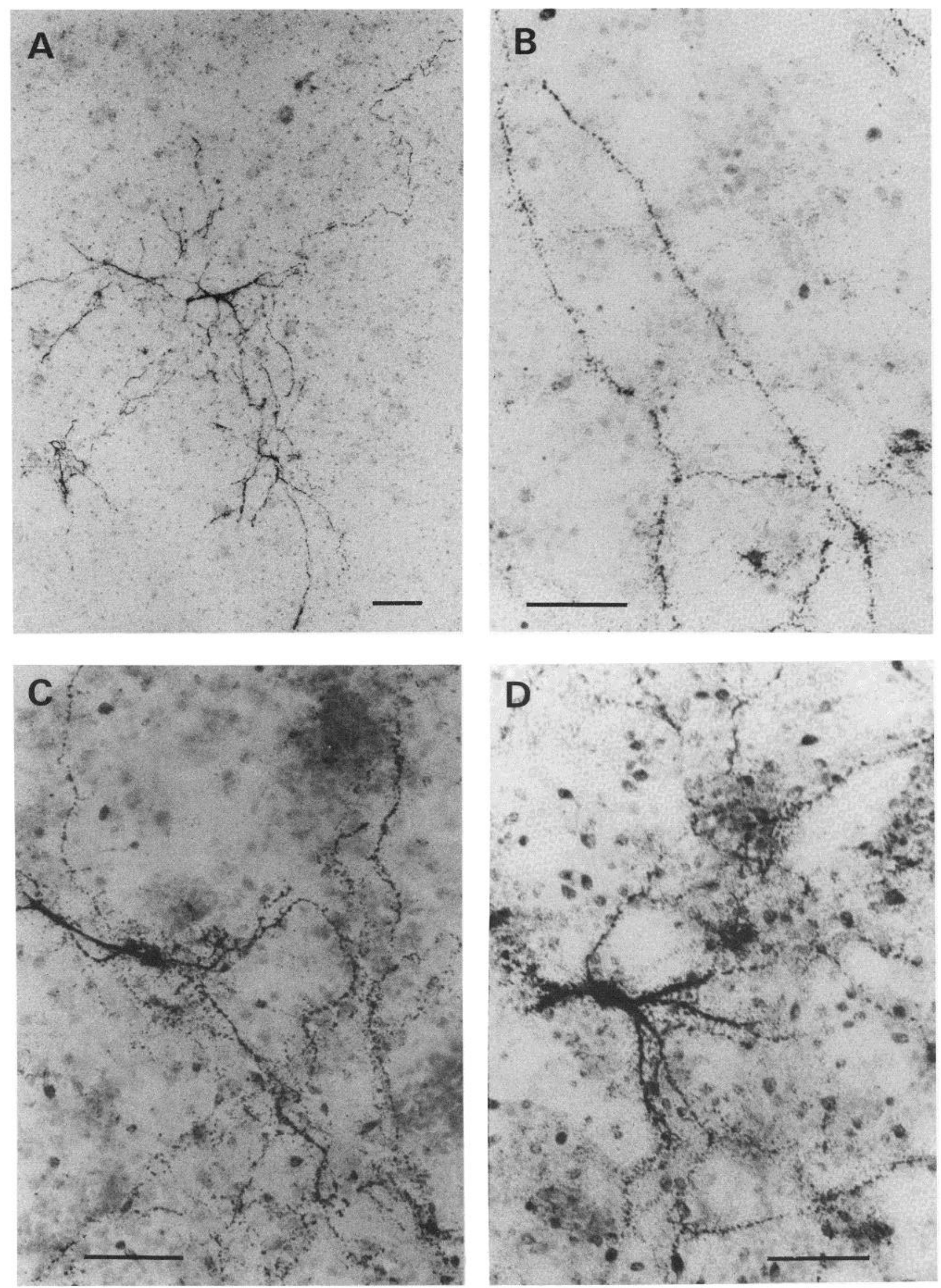

Figure 5. AChE-positive neurons in cultures of septal cells grown in the presence of gangliosides. Cultures were taken for staining 10 days after plating. The cytochemical procedure visualized the cell body and processes of $A C h E$-positive neurons $(A)$. $B$, straight AChE-positive processes only observed in ganglioside-treated cultures. Ganglioside-treated cultures contained no flat non-neuronal cells, resulting in a background lighter than that of control cultures. Furthermore, silver sulfite crystals had a tendency to diffuse, resulting in a slightly blurred picture of the processes. C, AChE-positive neuron in control culture; $D$, AChE-positive neuron in culture grown in the presence of $0.5 \mathrm{mg} / \mathrm{ml}$ of a ganglioside mixture. Bars, $100 \mu \mathrm{m}$. 


\section{ChAT ACTIVITY}

\section{(pmol/min/dish)}

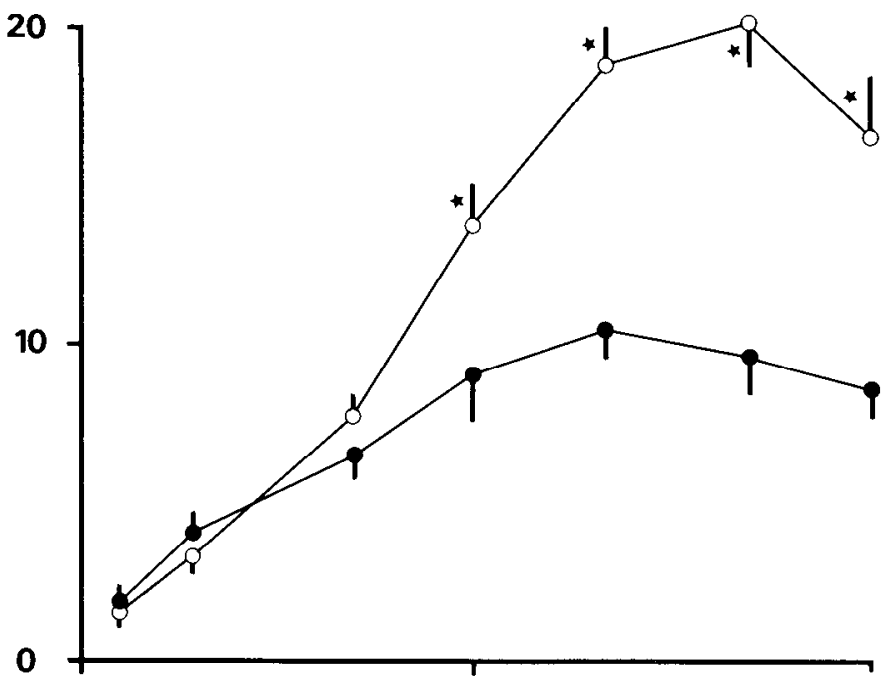

0

\section{0}

\section{DAYS AFTER PLATING}

Figure 6. Effect of gangliosides on ChAT activity in cultures of dissociated septal cells. The cells were grown in the absence $(\boldsymbol{)})$ or presence $(O)$ of a ganglioside mixture $(0.5 \mathrm{mg} / \mathrm{ml}$, present during the entire culture time). Bars represent SEM. *, significantly different from corresponding control levels, $p$ $<0.01 ; n=4$ to 12 .

TABLE $V$

Effect of gangliosides on NGF-mediated increase in ChAT activity in cultures of septal cells

The cells were grown for 10 days. NGF $(0.5 \mu \mathrm{g} / \mathrm{ml})$ and gangliosides $(0.5$ $\mathrm{mg} / \mathrm{ml}$ of a ganglioside mixture) were added to the medium and were present during the entire culture time.

\begin{tabular}{lccc}
\hline & Proteins & \multicolumn{2}{c}{ ChAT Activity } \\
\hline & $\mu g /$ dish & pmol/min/dish & $\begin{array}{c}\text { pmol/min } / \mu g \\
\text { of protein }\end{array}$ \\
Controls & $238 \pm 6^{a}$ & $4.72 \pm 0.32$ & $0.020 \pm 0.001$ \\
Gangliosides & $194 \pm 10^{b}$ & $7.78 \pm 0.58^{b}$ & $0.040 \pm 0.001^{b}$ \\
NGF & $236 \pm 9^{b}$ & $11.51 \pm 0.90^{b}$ & $0.049 \pm 0.003^{b}$ \\
NGF + gangliosides & $213 \pm 5^{b}$ & $10.85 \pm 0.43^{b}$ & $0.051 \pm 0.001^{b}$ \\
\hline
\end{tabular}

a Values are mean \pm SEM, $n=12$

${ }^{b}$ Significantly different from controls, $p<0.01$.

been observed in cultures of cells dissociated from white matter (type 2 astrocytes; Raff et al., 1983). These type 2 astrocytes bind tetanus toxin which attaches itself to gangliosides $\mathrm{GD}_{1 \mathrm{~b}}$ and $\mathrm{GT}_{1 \mathrm{~b}}$ (VanHeyningen, 1974), and they are recognized by an antibody which selectively binds to tetrasialogangliosides (GQ). Based on these observations, it could be postulated that the incorporation of complex gangliosides into membranes of astrocytes not containing them caused the transformation in process-bearing cells observed in the present study. However, type 2 astrocytes retain their morphological appearance in uncoated dishes (Raff et al., 1983), whereas in our cultures the effect was dependent on coating with polycationic substrates. Furthermore, the transformation was caused not only by ganglioside mixtures containing complex gangliosides, but also by the purified small gangliosides $\mathrm{GD}_{1 \mathrm{a}}$ and $\mathrm{GM}_{1}$. The mechanism by which exogenous gangliosides change astrocytic morphology therefore remains unclear. Gangliosides might alter the interaction between astrocytes and the coated surface of the culture dish. Otherwise, gangliosides might be preferentially incorporated into neuronal membranes and then alter the interaction between neurons and astrocytes. The fact that gangliosides were ineffective in uncoated dishes, in which astrocytes grow without contact to neurons, is compatible with such a view.

Besides changing the morphology of astrocytes, gangliosides altenuated the proliferation of these cells. A similar effect has been reported to occur with 3T3, cells, a fibroblastic cell line, of which the rate of proliferation was reduced by exogenous gangliosides (Bremer et al., 1984). In that study, gangliosides were found to inhibit the autophosphorylation of the receptors for platelet-derived growth factor. It therefore seems possible that the attenuation of astrocytic proliferation induced by gangliosides might be a consequence of a reduced response to growth-stimulating factors. However, it cannot be excluded that the reduced rate of astrocytic proliferation is secondary to the ganglioside's effect on the morphology of these cells.

It has been reported that the administration of gangliosides to lesioned rats promotes the sprouting of motoneurons (Gorio et al., 1980, 1983; Robb and Keynes, 1984) and the regeneration of dopaminergic neurons (Agnati et al., 1983; Toffano et al., 1983, 1984). Furthermore, an accelcrated recovery of hippocampal ChAT activity induced by gangliosides in animals with septal lesions has been interpreted as a reflection of facilitated regrowth of cholinergic fibers (Wojcik et al., 1982). Given these findings, we anticipated that gangliosides may stimulate the growth of cholinergic fibers in our cultures. The finding that gangliosides failed to promote fiber growth but elevated the activity of ChAT of cholinergic neurons suggests the possibility that the increase in ChAT activity observed in vivo (Wojcik et al., 1982) is due to an increased ChAT activity in cholinergic fibers that survived the septal lesions.

It has been hypothesized that gangliosides might stimulate growth of neuronal fibers by potentiating the effects of growth factors (Gorio et al., 1983). Our finding that gangliosides failed to potentiate the NGF-mediated increase in ChAT activity in cultures of septal cells does not support such a view. Nevertheless, since gangliosides elevated ChAT activity in the absence of NGF, and since the increases caused by NGF and gangliosides were not additive, it may be that gangliosides eventually act, at least in part, through a mechanism similar to that for NGF. However, the relative ChAT activity in septal cultures rose with increasing cell density (Hefti et al., 1985), suggesting a stimulatory effect of cell-cell interactions on the expression of this enzyme. The reduction of astrocyte number in ganglioside-treated cultures favors neuron-neuron interactions, which could result in elevated ChAT activity.

Comparing reported effects of gangliosides in vitro with those obtained in vivo makes it apparent that effective concentrations used in vitro are higher than the concentrations which can be expected to be reached after systemic administration in vivo. Concentrations effective in vilro ranged from $0.05100 .75 \mathrm{mg} / \mathrm{rml}$ of medium (Roisen et al., 1981; Leon et al., 1982; Rybak et al., 1983; Spero and Roisen, 1984; cf. Fig. 4 of the present study). Ten to 50 $\mathrm{mg} / \mathrm{kg}$ of body weight are normally administered in vivo to stimulate fiber growth (Gorio et al., 1980; Sparrow and Grafstein, 1982; Wojcik et al., 1982; Agnati et al., 1983; Karpiak, 1983; Toffano et al., 1983, 1984; Robb and Keynes, 1984). The discrepancy might be taken as an indication that the findings obtained in vitro are not relevant as models for the ganglioside-mediated effects occurring in vivo. However, in our ganglioside culture system, the effective ganglioside concentration is dependent on the concentration of serum in the medium. Lower concentrations of gangliosides are needed in the absence of serum (unpublished observations).

Regeneration of neuronal fibers is common in the PNS but not in the CNS (for reviews, see Raisman, 1977; Björklund and Stenevi, 1979; Moore, 1980). A difference in properties of central and peripheral glial cells seems to be the basis of this diversity, since both central and peripheral neurons regenerate in an environment of peripheral glia (David and Aguayo; 1981; Richardson et al., 1984). Central glial cells fail to promote regeneration, and their rapid proliferation after brain lesions might even produce a mechanical barrier preventing neuronal growth (Kiernan, 1979). The attenuation of 
astrocytic growth in vitro produced by gangliosides therefore might represent the basis of their ability to promote regenerative processes in vivo.

\section{References}

Adler, R., M. Manthorpe, S. D. Skaper, and S. Varon (1981) Polyornithineattached neurite-promoting factors (PNPFs). Culture sources and responsive neurons. Brain Res. 206: 129-144

Agnati, L. F., K. Fuxe, L. Calza, F. Benefanti, L. Cavicchioli, G. Toffano, and M. Goldstein (1983) Gangliosides increase the survival of lesioned nigral dopamine neurons and favour the recovery of dopamincrgic synaptic function in striatum of rats by collateral sprouting. Acta Physiol. Scand. 119: $347-363$

Ando, S. (1983) Gangliosides in the nervous systern. Neurocherr. Int. 5 . 507-537.

Björklund, A., and U. Stenevi (1979) Regeneration of monoaminergic and cholinergic neurons in the mammalian central nervous system. Physiol. Rev. 59: 62-100.

Bocchini, V., and P. V. Angeletti (1969) The nerve growth factor: Purification as a 30,000-molecular weight protein. Proc. Natl. Acad. Sci. U. S. A. 64. 787-794

Bradford, M. M (1976) A rapid and sensitive method for the quantitation of microgram quantities of protein utilizing the principle of protein-dye binding Anal. Biochem. 72: 248-254.

Bromer, E. G., S. Hakamori, D. F. Bowen-Pope, E. Raines, and R. Ross (1984) Ganglioside-mediated modulation of cell growth, growth factor binding, and receptor phosphorylation. J. Biol. Chem. 259: 6818-6825.

Byrne, M. C., R. W. Ledeen, F. J. Roisen, G. Yorke, and J. R. Scalafan (1983) Ganglioside-induced neuritogenesis: Verification that gangliosides are the active agents, and comparison of molecular species. J. Neurochem. 41: 1214-1222

Ceccarelli, B., F. Aporti, and M. Finesso (1976) Effects of brain gangliosides on functional recovery in experimental regeneration and reinnervation. Adv. Exp. Med. Biol. 71: 275-293.

David, S., and A. J. Aguayo (1981) Axonal elongation into peripheral nervous system "bridges" after central nervous system injury in adult rats. Science 214: $931-933$

Dimpfel, W. W. Moller, and U. Mengs (1981) Ganglioside-induced neurite formation in cultured neuroblastoma cells. In Gangliosides in Neurological and Neuromuscular Function, Development and Repair, M. M. Rapport and A. Gorio, eds., pp. 119-134, Raven Press, New York

Facci, L., A. Leon, G. Toffano, S. Sonnino, R. Ghidoni, and G. Tettamanti (1984) Promotion of neuritogenesis in mouse neuroblastoma cells by exogenous gangliosides. Relationship between the effect and the cell association of ganglioside $\mathrm{GM}_{1}$. J. Neurochem. 42: 299-305.

Ferrari, G., M. Fabris, and A. Gorio (1983) Gangliosides enhance neurite outgrowth in PC12 cells. Dev. Brain Res. 8: 215-221.

Fishman, P. H., and R. O. Brady (1976) Biosynthesis and function of gangliosides. Science 194: 906-915

Fonnum. F. (1975) A rapid radiochemical method for the determination of choline acetyltransferase. J. Neurochem. 24: 407-409.

Geneser-Jensen, F. A., and T. E. Blackstad (1971) Distribution of acetylcholinesterase in the hippocampal region of the guinea pig. I. Entorhinal area, parasubiculum, and pre-subiculum. Zellforschung 114: 460-481.

Gorio, A., G. Carmignoto, L. Facci, and M. Finesso (1980) Motor nerve sprouting induced by ganglioside treatment. Possible implications for gangliosides on neuronal growth. Brain Res. 197: 236-241.

Gorio A., P. Marini, and R. Zanoni (1983) Muscle reinnervation. III. Motoneuron sprouting capacity, enhancement by exogenous gangliosides. Neuroscience 8: 417-429.

Hefti, F., J. Hartikka, F. Eckenstein, H. Gnahn, R. Heumann, and M. Schwab (1985) Nerve growth factor (NGF) increases choline acetyltransferase but not survival or fiber outgrowth of cultured septal cholinergic neurons. Neuroscience 14: 55-68.

Karpiak, S. E. (1983) Ganglioside treatment improves recovery of alternation behavior after unilateral entorhinal cortex lesion. Exp. Neurol. 81: 330-339.

Kiernan, A. (1979) Hypotheses concerned with axonal regeneration in the mammalian nervous system. Biol. Rev. 54: 155-197.

Leon, A., L. Facci, D. Benvegnu, and G. Toffano (1982) Morphological and biochemical effects of gangliosides in neuroblastoma cells. Dev. Neurosci. 5: $108-114$.

Lim, R., K. Mitsunobu, and W. K. P. Li (1973) Maturation-stimulating effect of brain extract and dibutyryl cyclic AMP on dissociated brain cells in culture. Exp. Cell Res. 79: 243-246.

Mains, R. A., and P. H. Patterson (1973) Primary cultures of dissociated sympalhetic neurons. I. Establishment of long-term growth in culture and studies of differentiated properties. J. Cell Biol. 59: 329-345.

Manthorpe, M., R. Adler, and S. Varon (1979) Development, reactivity and GFA immunofluorescence of astroglia-containing monolayer cultures trom rat cerebrum. J. Neurocytol. 8: 605-621.

Metzger, H., and E. Linder (1981) Forskolin-a novel adenylate cyclase activator. Med. Sci. 9: 99-104.

Moore, R. Y. (1980) Regeneration in the mammalian nervous system. Ann N. Y. Acad. Sci. 339: 102-114.

Morgan, J. I., and W. Seifert (1979) Growth factors and gangliosides: A possible new perspective in neuronal growth control. J. Supramolec. Struct. 10: 111-124

Norido, F., R. Canella, R. Zanoni, and A. Gorio (1984) Development of diabetic neuropathy in the C57BL/Ks $(d b / d b)$ mouse and its treatment with gangliosides. Exp. Neurol. 83: 221-232.

Raff, M. C., E. R. Abeny, J. Cohen, R. Lindsay, and M. Noble (1983) Two types of astrocytes in cultures of developing rat white matter: Differences in morphology, surface gangliosides, and growth characteristics. J. Neurosci. 3: $1289-1300$.

Raisman, G. (1977) Formation of synapses in the adult rat after injury Similarities and differences between a peripheral and central nervous site. Philos. Trans. R. Soc. Lond. (Biol.) 278: 349-359.

Richardson, P. M., V. M. K. Issa, and A. J. Aguayo (1984) Regeneration of long spinal axons in the rat. J. Neurocytol. 13: 165-182

Robb, G. R., and R. J. Keynes (1984) Stimulation of nodal and terminal sprouting of mouse motor nerves by gangliosides. Brain Res. 295: 368371.

Roisen, F. J., H. Bartfield, R. Nagele, and G. Yorke (1981) Ganglioside stimulation of axonal sprouting in vitro. Science 214: 577-578.

Rüegg, U. T., and F. Hefti (1984) Growth of dissociated neurons in culture dishes coated with synthetic polymeric amines. Neurosci. Lett. 49: 319324

Rybak, S., I. Ginzburg, and E. Yavin (1983) Gangliosides stimulate neurite outgrowth and induce tubulin mRNA accumulation in neural cells. Biochem. Biophys. Res. Cormunu. 116: 974-980.

Seamon, K. B., W. Padgett, and J. W. Daly (1981) Forskolin: A unique diterpene activator of adenylate cyclase in membranes and in intact cells. Proc. Natl. Acad. Sci. U. S. A. 78: 3363-3367.

Shapiro, D. L. (1973) Morphological and biochemical alterations in fetal rat brain cells cultered in the presence of monobutyryl cyclic AMP. Nature 241: 203-204

Sparrow, J. R., and B. Grafstein (1982) Sciatic nerve regeneration in ganglioside-treated rats. Exp. Neurol. 77: 230-235.

Spero, D. A., and F. J. Roisen (1984) Ganglioside-mediated enhancement of the cytoskeletal organization and activity in neuro-2a-neuroblastoma cells. Dev. Brain Res. 13: 37-48.

Suda, K., Y. A. Barde, and H. Thoenen (1978) Nerve growth factor in mouse and rat serum: Correlation between bioassay and radioimmunoassay detcrminations. Proc. Natl. Acad Sci. U. S. A. 75: 40424046.

Tettamanti, G., F. Bonali, S. Marchesini, and V. Zambotti (1973) A new procedure for the extraction, purification and fractionation of brain gangliosides. Biochim. Biophys. Acta 296: 160-170.

Toffano, G., G. Savoini, F. Moroni, G. Lombardi, L. Calza, and L. F. Agnati (1983) $\mathrm{GM}_{1}$ ganglioside stimulates the regeneration of dopaminergic neurons in the central nervous system. Brain Res. 261: 163-166.

Toffano, G., G. E. Savoini, F. Morni, G. Lombardi, L. Calza, and L. F. Agnati (1984) Chronic $\mathrm{GM}_{1}$ ganglioside treatment reduces dopamine cell body degeneration in the substantia nigra after unilateral hemitransection in rat. Brain Res. 296: 233-239.

VanHeynigen, W. E. (1974) Gangliosides as membrane receptors for tetanus toxin, cholera toxin and serotonin. Nature 249: 415-417.

Wojcik, M., J. Ulas, and B. Oderfeld-Nowak (1982) The stimulating effect of ganglioside injections on the recovery of choline acetyltransferase and acetylcholinesterase activities in the hippocampus of the rat after septal lesions. Neuroscience 7: 495-499. 